\title{
Dynamics and Constraints of State-led Global City Formation in Emerging Economies: The Case of Shanghai
}

\author{
Le-Yin Zhang \\ Development Planning Unit, University College London
}

\begin{abstract}
This article seeks to contribute to a better understanding of the role of the state in influencing the formation of global cities in emerging economies, and highlights the complexity of this role due to challenging external environments, divergent interests of state actors, and socio-economic and institutional constraints that these actors are under. At an empirical level, it examines the progress of Shanghai in its state-led development as an emerging global city and the respective roles of the national and local governments in this process.
\end{abstract}

Note: This is the final version of the manuscript published on Urban Studies, 51(6), 1161-1178, May 2014. An online version was published in July 2013. 


\section{Introduction}

The formation of the global/world cities and the role of the state in this process is seriously under-explored (Sassen 1991 \& 2001; Friedmann 1995 \& 2001; Olds \& Yeung 2004). Despite this, however, urban planners and city authorities, especially those in emerging economies, have demonstrated remarkable interest in state-led global/world city formation (Olds and Yeung 2004). The contrast here raises two important research questions. First, what are the chances for leading cities of emerging economies to become global/world cities? Second, to what extent can the state in emerging economies facilitate this formation? This article explores such questions in the context of Shanghai's emergence as a global city. Emerging economies here are loosely defined as major developing countries that are characterised by fast economic growth and industrialisation, and increasing integration into the global trading system (OECD 2008).

Shanghai's re-emergence as a leading world city had been anticipated. In fact, along with Hong Kong and Singapore, Shanghai was for the period of 1919-1939 the largest of the three 'sub-regional' financial centres in Asia (Jones 1992). But the city declined, first due to the Japanese occupation (1937-1945), and then, after the foundation of the PRC in 1949, a socialist system that practised 'financial repression' and an insular planned economy (Jao 2003). With the rise of the Chinese economy following its reform and open-door policy from the late 1970s, however, it is widely expected (e.g. Friedmann 1995; Mainelli \& Yeandle 2007) that Shanghai will once again become a significant player in international finance. On the other hand, turning Shanghai into a global/world city has been a much publicised Chinese 'state project' since at least the early 1990s, if 
not earlier (Zhang 2003; Wu 2009). However, numerous reviews of Shanghai's prospects (Shi \& Hamnett 2002; Jao 2003; McCauley \& Chan 2007, Jarvis 2011; Subacchi et al 2012) either as an international financial centre or as a global city have consistently sounded a cautious note, especially in terms of its competition with Hong Kong. This is despite Shanghai's improvement on several fronts since the early 2000 s (see Part 2).

So to what extent has Shanghai succeeded in becoming a global city? What role has the state played in this process? Furthermore, what does Shanghai's experience tell us about the capacity and constraints of the state in emerging economies to facilitate global city formation? These are the important questions to be explored.

The rest of this article proceeds as follows. Part One reviews the relevant literature. Part Two discusses the vision of this 'state project' and evaluates the evidence on Shanghai's progress in global city formation. Part Three explores the underlying factors. Part Four concludes.

\section{Perspectives on Global/World City Formation and the Role of the State}

In order to develop an analytical framework for the empirical analysis, we first introduce the concept of the global/world city. We then discuss theoretically the scope for leading cities in emerging economies to become global/world cities. Finally, the potential role of the state in this formation is considered.

\subsection{Defining world/global cities}


Although Hall (1966) did much to popularise the idea of world cities, it was Friedman and Wolff (1982) who undertook the conceptual ground-breaking work. In the context of economic restructuring in the world-economy starting from the 1970s and adopting a world-systems perspective, they conceptualised the world city as

(i) 'an instrument for the control of production and market organization' by transnational capital and

(ii) a junction between the national economy and the world economy.

They saw these cities as 'major sites for the concentration and accumulation of international capital', tightly connected with each other and occurring 'exclusively in core and semi-core regions' (p. 59). Friedmann's (1986) subsequent formulation of 'The World City Hypothesis' further linked these cities to the 'new international division of labour', characterising them as the 'basing points' for global capital.

In contrast, Sassen (1991) distinguishes 'global cities' from 'world cities' and insists that global cities are a new type of economic coordinating units, specific to the era of globalisation since the 1980s. In the context of spatially dispersed, but globally integrated economic activities, global cities function 'as command points in the organization of the world economy, as sites for the production of innovations in finance and advanced service for firms, and as key marketplaces for capital.' (Sassen 1991, p. 338). Sassen (1991) also recognises that these cities do not simply compete with each other, but function as one transterritorial marketplace.

Sassen's $(1991,2001)$ focus on the provision of advanced services by global cities stresses that these cities function similarly as international financial centres, defined as localities with an intensive concentration of a wide variety of international financial 
businesses and transactions enjoying both agglomeration and scale economies in financial transactions (Kindleberger 2000; Z/Yen Ltd 2005). Sassen's global cities also possess other industries supporting the capability of global corporate control and various amenities to maintain the life-style of the key professionals.

Synthesising Sassen's emphasis on the provision of advanced services by global cities, Castells' (1996) idea of a 'global network' of urban centres and Braudel's (1984) insight into the inherent monopolistic tendency of capitalism led Taylor (2000) to conceptualise world/global cities as the highly concentrated loci of 'unique knowledge complexes' that exploit their monopoly power based on economic reflexivity. He suggests that contemporary globalisation has led to a 'World City Network', defined as an interlocking network where cities are connected through the activities of trans-nodal agents, most importantly transnational advanced service firms. 'World city-ness' can then be measured in terms of the level of provision for advanced producer services relative to the top scoring city, or its 'interlock connectivity' (Taylor 2000, 2004). A major advantage of Taylor's approach is that a city's 'world city-ness' can be objectively measured.

\subsection{The chances for latecomers}

The three perspectives referred to above have different implications for the prospects of new global cities in emerging economies. Although the World City Hypothesis itself has relatively little to say on this issue except that world cities only occur in core or semiperiphery regions (Friedmann 1986), the world-systems theoretical framework is nevertheless insightful. The framework conceptualises the contemporary world economy as a hierarchy, within which participating areas play differentiated roles either as core, semi-periphery, or periphery. While the core areas have more core-like (defined as 
monopolistic and highly profitable) production processes (e.g. finance) and strong states, the periphery areas have more periphery-like (defined as competitive and less profitable) production processes and weaker states. In contrast, the semi-periphery is in transition towards the core, and is therefore the most dynamic type of area (Wallerstein 2004). Thus the chance of global city formation in an emerging economy depends on the progress of its national economy, and, in turn this formation can strengthen the home economy's bid to raise its position.

The Global City Model (Sassen 2001) has somewhat different implications. Since it regards global cities as the production sites of highly specialised corporate services and financial innovations, and as marketplaces for these services and products, there is greater room for manoeuvre at the city level. In other words, the fortunes of emerging national economies and their nascent global cities need not be synchronised theoretically. Much would depend on how quickly the city itself can develop the capability of corporate control, acquire the necessary infrastructure and lifestyle, and attract other market players. Studies of international financial centres suggest that, while the more established centres benefit from the forces of centralisation due to scale economies, agglomeration economies and their 'endowed capacities', newly emerging centres can, by contrast, benefit from the forces of decentralisation thanks to outsourcing, regionally specialised knowledge, and emerging localised demand associated with increasing inward foreign investment and fast economic growth. There is also scope for latecomers to increase their chances through policy initiatives (Jarvis 2011).

Finally, while the World City Network school is light on theorisation, it has done much to deepen our understanding of city' network connectivity and power, defining the last as 
both 'to power over' other cities and an ability to attract advanced service firms (Taylor 2004). In particular, a Globalising City Index has been formulated to distinguish two kinds of driving forces, namely 'place power' and 'network power', underpinning two types of globalising cities. While the first type draws power from being the headquarters (therefore command centres) of top firms in the world, the second type draws power from high connectivity (Taylor et al 2011). This analysis implies that global city formation can benefit from either strengthening headquarter functions, or improving connectivity, or a combination of both.

\subsection{The role of the state in global city formation}

While the dominant World City Hypothesis and the Global City Model provide limited guidance on the role of the state in global city formation, insights can be drawn from elsewhere in the literature. Taylor's (2000) analysis of the distribution of world cities shows that while a combination of decentralisation and large national economies tend to be associated with multiple world cities, centralisation and medium-sized economies tend to produce one dominant world city in each state.

On the other hand, examining the experiences of New York, Tokyo and Seoul, Hill and Kim (2000) distinguish two types of global cities, namely a 'market-centred, bourgeois type' versus a 'state-centred, political-bureaucratic type'. Their work usefully contrasts some of the characteristics of the two types and highlights a crucial link between the state-centred global city and the developmental state. They argue that Tokyo was not primarily a global basing-point for the operations of stateless transnational corporations (TNCs), but mainly a national basing-point for the global operations of Japanese TNCs. They further state that the global control apparatus represented by Tokyo resides in the 
financial and industrial policy networks under the guidance of government ministries, rather than networks of transnational service firms.

Olds and Yeung (2004) propose a useful typology of three kinds of global cities: 'hyper global cities'; 'emerging global cities'; 'global city-states'. Their discussion of what they see as the relative disadvantage of emerging global cities is particularly relevant. Relative to 'hyper global cities' such as New York and London, emerging global cities are regarded to be less integrated into the global economy, functioning mainly as 'coordination/channelling centres responsible for receiving or channelling inward flows' (p. 506). Relative to the 'global city-states' (e.g. Singapore and Hong Kong), emerging global cities are said to face more potential competition from other urban centres in their home country, and are 'governed in a relatively more complex, less coherent, and less strategic fashion' (p. 508). Furthermore, they are constrained by the tensions inherent in national-versus-urban politics. Finally, the lack of a colonial past generally makes the emerging global cities less open, cosmopolitan and attractive, compared to global citystates. The critical condition for emerging global cities is the sustainability of national efforts in developing particular cities to become global cities' (p. 507).

The experience of Tokyo (Hill and Kim 2000) and Singapore (Olds and Yeung 2004) help shed light on the prospects of Shanghai as a global city: they highlight the important role of a developmental state on the one hand, and the disadvantage of being an emerging global city on the other. The Chinese state is not a typical developmental state. In comparison with the paradigmatic Japanese developmental state, the Chinese state is characterised by 'fragmented authoritarianism' arising from a tradition of administrative decentralisation, has weaker capacity, and is less inclined and able to work with the private sector because of its socialist ideology (Beeson 2009). Moreover and related to 
the ideological difference with the West, the Chinese state faces a much less permissive external environment compared to the Japanese state (ibid). This is further aggravated by the direct role of the state in emerging Chinese state-owned TNCs and sovereign funds (Wooldrige 2012). The implication is that China's path towards global ascendance is likely to be more contentious than Japan's. So Shanghai's will be similarly difficult in its pursuit of global city status relative to Tokyo's.

Weiss' (1998) emphasis on 'managed openness' and Chang (2003)'s institutionalist perspective on the role of the state in structural change are also relevant here. In the context of globalization and opening-up, 'managed openness' requires the state to adopt "a framework of analysis and policy choice that is both "open" to the benefits of international economic flows and relationships, but "managed" in terms of their effects' (Weiss 1998, p. 127). Following Michael Lind, Weiss (1997, p. 24) argues that efforts to maintain state power in the context of globalisation involve the 'reconstitution of power around the consolidation of domestic and international linkages' by building power alliances. The traditional 'integral state' is being replaced by a 'catalytic state'. Here states 'achieve their goals less by relying on their own resources than by assuming a dominant role in coalitions of states, transnational institutions, and private-sector groups.' Weiss suggests that the strength of a 'catalytic' state in external inter-state coalition depends critically on the strength of the state-business alliance at home. Here the state's capacity is strongly affected by its domestic public-private relationship. On the other hand, as an instance of effecting major structural change at the city level, state-led global city formation would oblige the state to show not only 'entrepreneurship in the sense of providing the "vision" for the future and building new institutions', but also to manage the conflicts which would inevitably arise during the process of any structural change (Chang 2003, p. 46). 
To sum up, state-led global city formation in an emerging economy could be considered part of the state's strategy to lift its national economy from the periphery to the core, as well as developing a knowledge-based economy in the city. Challenging the established global cities is necessarily a difficult process. The state not only has to act as the planner, institution-builder and interest mediator, but also has to change itself and the ways it works. These represent major challenges for an emerging economy, and even more so for a transitional economy, defined as moving from a planned economy to a market economy and having weak market-supporting institutions (IMF 2000). In the case of China, while the party-state insists on dominant state ownership, which both underpins its domestic power, and draws economic strength from it, this also serves to alienate established international market players. How and to what extent has the state risen to these challenges? We seek to answer this question below by first examining the planning vision for Shanghai and the evidence of its progress as an emerging global city.

\section{Shanghai as an Emerging Global City - State Strategies and Outcomes}

\subsection{Strategic visioning and institutional building by the state}

Turning Shanghai into a global city has been characterised as a 'strategy-based state project' (Wu 2009). However, this strategy has been an evolving and intermittent one, marked by changing visions and unstable relationships between the central and local authorities. The State Council's (i.e. the central government) written approval of Shanghai's Comprehensive Plan (BSUPPA 1986) states

After several decades of hard work, Shanghai should be built into [a] socialist modern metropolis with prosperous economy, advanced science and technology, 
colourful culture, convenient transportation, sensitive information and handsome environment. It should also take the role of 'the important base' and 'the pioneer' in the construction of the modernization of our socialist country.

Evidently at that stage neither the Municipality nor the State Council had a global ambition for Shanghai.

Following the establishment of the Pudong New Area and the opening of the Shanghai Stock Exchange in 1990, however, the $14^{\text {th }}$ Chinese Communist Party Central Committee in 1992 called upon Shanghai to become the 'dragon head' of economic growth in the Yangtze River Delta and the whole Yangtze basin, and to turn itself into an international economic, financial and trade centre. This resulted from a major shift in the outlook of the Party following the intervention of the departing paramount leader Deng Xiaoping. The Party decided then to adopt a 'Socialist Market Economy', where significant public ownership of productive assets would co-exist with a dominant role of the market in resource allocation (Zhang 2006). This created an impetus for the publication of an influential research report by the Municipality (Leading Group 1994) ${ }^{1}$, Shanghai Towards the $21^{\text {st }}$ Century, in which an ambitious economic and social development strategy (1996-2010) was presented (see Table 1 for key planning targets). The report proposes to turn Shanghai into 'an international economic central city' by 2010.

\footnotetext{
${ }^{1}$ The Editorial Committee included Shanghai's mayor (as an honorary chairman) and a vicemayor as its chairman, as well as key staff from the Shanghai Municipality Development Research Centre.
} 
Table 1. Selected Strategic Targets and Actual Development, 1993-2010

\begin{tabular}{|c|c|c|}
\hline Indicators & $\begin{array}{l}\text { Targets } \\
(2010)\end{array}$ & Actual (2010) \\
\hline No. of foreign financial institutions and agencies & $>300$ & 173 \\
\hline No. of $\mathrm{HQ}$, regional $\mathrm{HQs}$ and subsidiaries of TNCs & $>500$ & 305 \\
\hline $\begin{array}{l}\text { No. of overseas subsidiaries owned by Shanghai- } \\
\text { based companies }\end{array}$ & $>1000$ & $179^{a}$ \\
\hline Ratio of foreign trade to GDP & $>50 \%$ & $148.0 \%{ }^{b}$ \\
\hline Share of volume of domestic securities transactions & $80 \%$ & $67.1 \%(2009)^{\mathrm{C}}$ \\
\hline GDP (billion Yuan) & 2000 & 1687 \\
\hline Average annual growth rate of GDP (2001-2010) & $9.8 \%$ & $11.54 \%$ \\
\hline Proportion of the three industries in GDP & 1\%:39\%:60\% & $0.7 \%: 42.3 \%: 57 \%$ \\
\hline Population size (million) & 15.6 & $23^{d}$ \\
\hline
\end{tabular}

Sources: Shanghai Statistical Yearbook, 2011; Leading Group of "Shanghai towards the 21st Century" Research Project 1994; 2010 Statistical Communiqué on Economic and Social Development in Shanghai.

Notes: a: refers to those newly established in 2010 only. b: the ratio peaked in 2007 at 179.3\%; c. includes transactions in shares and bonds. d: Including registered population and those migrant residents staying for 6 months or longer.

Further momentum was created in 2001, when the State Council's letter of approval for Shanghai's Master Plan indicated that Shanghai should become an international economic, financial, trade and shipping centre. Since then, the mission for Shanghai has been shorthanded as 'A Dragon Head; Four Centres'. However, there followed almost a decade of relative policy silence from the national government. Two factors may explain 
this. First, the national politics turned against Shanghai from 2003 (see Part 3). Second, Shanghai was pre-occupied with the preparation and delivery of the World Expo, another 'state project', held in 2010.

It was not until April 2009 that policy momentum seems to have returned to Shanghai. With the world economy in deep recession and the Chinese economy in global ascendance, international expansion became high on the central government's agenda. In response to Shanghai's submission, Accelerating the Development of Modern Services and Advanced Manufacturing in Shanghai and Making Shanghai an International Financial Centre and International Shipping Centre, the State Council reiterated that promoting the development of Shanghai as an international financial and shipping centre was 'an important measure for our country's modernisation and further reform and opening-up' (SMG, 2011). It further stated '[B]y 2020, Shanghai should strive to basically have completed its construction as an international financial centre that is compatible with China's national economic power and the international status of renminbi.' This indicated that Shanghai's project to become a global city has for the first time acquired unprecedented national significance.

\subsection{Effects}

Three different kinds of evidence are used here to assess Shanghai's progress in global city formation: 1) Shanghai's changing ranking in the Global Financial Centre Index (GFCl) reports; 2) Its changing interlock connectivity measurements; 3) The outcomes of Shanghai's strategic targets. Compiled twice a year by the London-based Z/Yen Group since March 2007, the GFCI reports calculate ratings and rankings for several dozen cities by using a 'factor assessment model'. This model combines two different types of 
input, i.e. instrumental factors (external indices) and assessment by professionals responding to on-line surveys (Mainelli and Yeandle 2007). Covering 77 financial centres, the most recent report (March 2012), at the time of writing, uses 80 external indices and responses from 1778 financial service professionals (Yeandle et al 2012). The theoretical maximum rating of GFCl is always 1,000 . By contrast, a city's interlock connectivity is calculated based on actual service values, which represent the importance of a city within a firm's world-wide office network (see Taylor 2004, pp. 63-64, for methodology details).

\subsubsection{Becoming a global financial centre (GFC)}

Based on the available GFCI reports, Table 2 and Figure 1 illustrate several important features. First, all the four Chinese cities (Hong Kong, Shanghai, Beijing, and Shenzhen) and Tokyo experienced a significant rise in ratings between March and September 2009. The jump is especially big for Shanghai and Beijing, but also obvious for Hong Kong and Tokyo. This illustrates the impact of the 2008 financial crisis and the relative rise of AsiaPacific region, rather than just China. Second, related to the first point, Shanghai's ranking in the GFCl reports saw a major improvement between March 2009 and September 2011 (from $35^{\text {th }}$ to $5^{\text {th }}$ ). Indeed, it came to tie with Tokyo (in $5^{\text {th }}$ place) in the $9^{\text {th }}$ edition (March 2011) and overtook Tokyo in the $10^{\text {th }}$ edition (September 2011) (Table 2). But it had fallen to the $8^{\text {th }}$ place in March-2012 edition. This has been attributed to concerns about the lack of 'currency convertibility' (Yeandle 2012). 
Table 2. Changing ranking of selected GFCs

\begin{tabular}{|l|l|l|l|l|l|}
\hline $\begin{array}{l}\text { Ranking } \\
\text { (March. } \\
2012)\end{array}$ & City & $\begin{array}{l}\text { Rating } \\
\text { point (Mar. } \\
2012)\end{array}$ & $\begin{array}{l}\text { Ranking } \\
\text { (March 2007) }\end{array}$ & $\begin{array}{l}\text { Rating point } \\
\text { (March 2007) }\end{array}$ & $\begin{array}{l}\text { Change in } \\
\text { rating point } \\
\text { (March 2007- } \\
\text { 2012) }\end{array}$ \\
\hline 1 & London & 781 & $=1$ & 765 & +16 \\
\hline 2 & New York & 772 & $=2$ & 760 & +12 \\
\hline 3 & Hong Kong & 754 & $=3$ & 684 & +70 \\
\hline 4 & Singapore & 729 & $=4$ & 660 & +69 \\
\hline 5 & Tokyo & 693 & 9 & 632 & +61 \\
\hline 8 & Shanghai & 687 & 24 & 576 & +111 \\
\hline 26 & Beijing & 644 & 36 & 513 & +131 \\
\hline 32 & Shenzhen & 638 & No ranking & No rating & na \\
\hline & & & & & \\
\hline
\end{tabular}

Source: www.zyen.com. Note: the March 2007 report and March 2012 report covered respectively 46 and 77 cities.

Third, Shanghai's most important competitor, Hong Kong, has done even better and maintained its lead over Shanghai since September 2009 (Figure 1). In fact, Hong Kong has since then consistently taken the $3^{\text {rd }}$ place globally, closing the distance from London (in the top place) in the September 2011 report (although the gap widens again in the March 2012 edition). Fourth and finally, between March 2010 and September 2011, Beijing joined the rank of the top 20 GFCs. Indeed, Beijing improved its rating more than Shanghai during 2007-2012 (Table 2). This would seem to suggest that 
Shanghai's post-2008 rise as a GFC is as much the effect of the 'state project' as the rise of the Chinese, or even regional, economy, since Beijing is not part of the 'state project', but a well-established gateway city to the Chinese market (Taylor et al 2011).

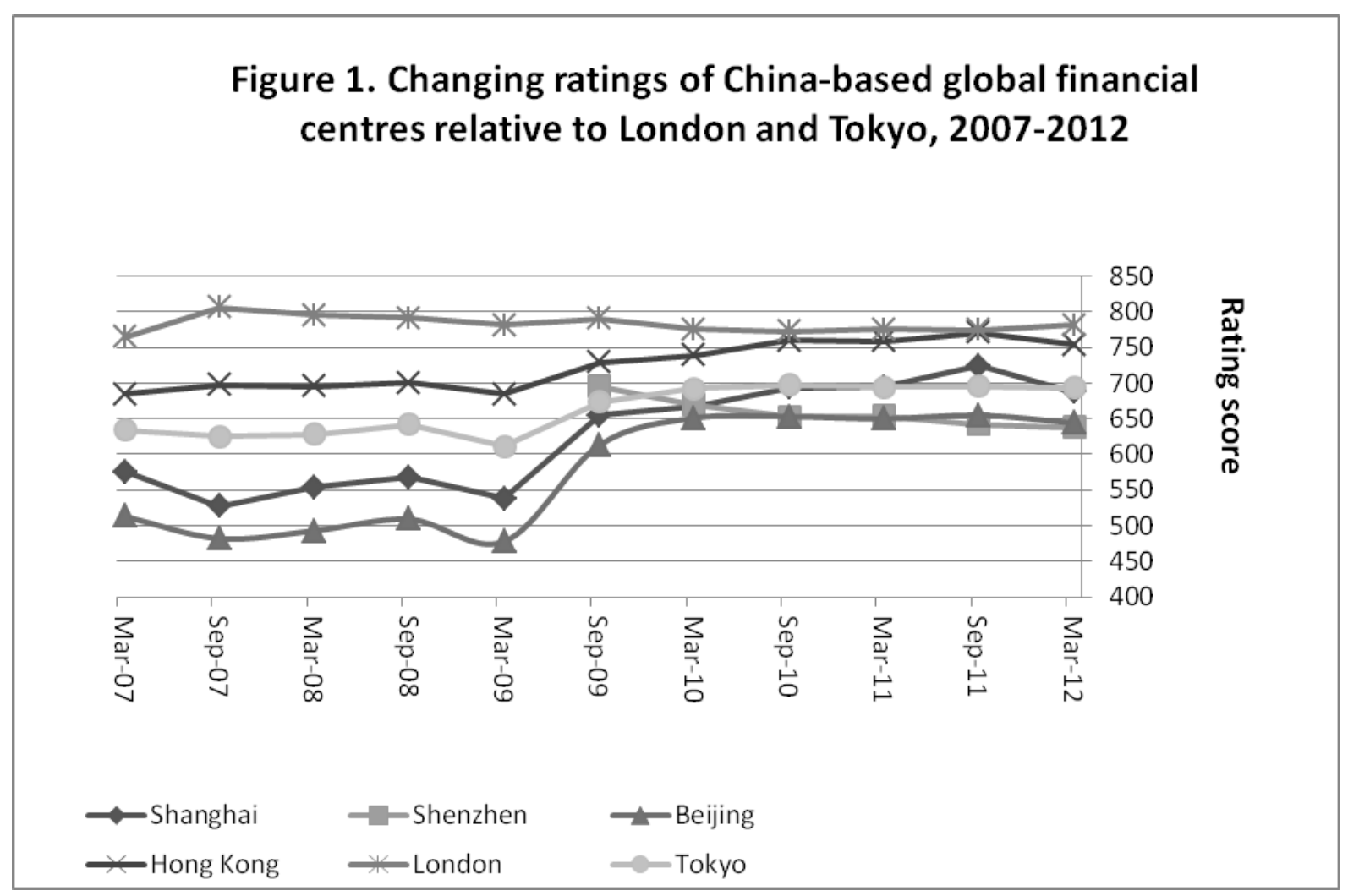

Source: The same as Table 2.

While the GFCI reports put Shanghai significantly ahead of Beijing, studies of the "World City Network' suggest otherwise. Three kinds of measurement have been taken: the command and control function, interlock connectivity and Globalisation Cities Index. While the function is indicated by the headquarter location of top service firms, the Index comprises of City Place Power (CPP) (50\%) and City Network Power (CNP) (50\%). CPP is overwhelmingly determined by a Business Command Index, derived directly from headquarter functions of the Forbes 2000 top firms, whereas CNP is represented by the 
city's network position in three sectors (business, financial and media services) in terms of connectivity. Based on 2008 data, Beijing is ranked the $9^{\text {th }}$ in CPP, compared with Hong Kong in the $22^{\text {nd }}$ place, and Shanghai in the $49^{\text {th }}$ place. However, Hong Kong, Shanghai and Beijing are respectively ranked as the $3^{\text {rd }}, 7$ th and $8^{\text {th }}$ city in terms of CNP. Indeed, Shanghai and Beijing are the two cities which improved most in global connectivity during 2000-2008. Finally, the overall Globalisation Cities Index, calculated as a percentage of New York's (100) is 53.75 for Hong Kong, 48.87 for Beijing and 43.37 for Shanghai (Taylor et al 2011).

Thus the combination of the GFCl reports and the analysis of Taylor et al (2011) show the following. First, there has been significant global city formation in Shanghai, Beijing and Hong Kong since the turn of the century. Second, this process has further accelerated in the wake of the 2008 financial crisis as a result of the relative strengthening of the Chinese and Asia-Pacific economies. Third, there is an intense competition between these three cities. It is also clear that these cities have different sources of power: while Beijing enjoys significant Place Power and moderate level of Network Power, Hong Kong enjoys limited Place Power, but high level of Network Power. In comparison, Shanghai enjoys a moderate level of Network Power, but very limited Place Power. Therefore, although the CFCl reports, no doubt reflecting the views of the on-line contributors, seem to have written off the prospect of Beijing as a real competitor as GFC, the race may still be open. Indeed, if the experience of Tokyo (relative to Osaka) is any guide (Ryoichi 2011), then Beijing stands a good chance.

Let us now turn to Shanghai's outcome in realising its strategic targets. Table 1 shows that Shanghai's performance has fallen short in several crucial areas. These include the number of foreign-funded financial institutions and transnational headquarters located in 
the city, the city's share in the domestic securities market and change in economic structure. However, Shanghai exceeded its planned targets in aggregate economic growth and economic openness. Socially, its population target was exceeded by 8 million: Shanghai's population has grown from $13 \mathrm{~m}$ in 1993 to $23 \mathrm{~m}$ by the end of 2010 . The next section focuses on the change in economic structure, especially the growth of financial and business services.

\subsubsection{Structural change}

Changing statistical definition before and after 2003 makes it difficult to identify precise structural changes over the past decade except at a broad level. However, several important changes are discernible. First, there has been a significant de-industrialisation. The share of manufacturing in total employment fell by 8.2 percentage points over 2000 2009. Nevertheless, the share of industry in GDP remains high at $42.3 \%$ as of 2010 , compared to the 2010 target of $39 \%$ in the 1994 Strategy (Table 1). Shanghai has thus a long way to go to transform itself into a service-oriented or knowledge-based economy.

Second, employment in high-value specialised financial and business services is low and its growth flat. As Table 3 shows, only 5 out of a total of 16 sectors have aboveaverage labour productivity. In descending order, these are: finance; real estate; information, computing and software; public administration and social organisations; and industry. However, the share of employment in finance and real estate is low, respectively $2.08 \%$ and $3.43 \%$ in 2009 . Moreover, both shares fell during the period. The fastest employment growth took place (in descending order) in scientific research and technical services; information, computing and software; leasing and business services; accommodation and restaurants; retail and wholesale trade. With the exception of 
information, computing and software, however, these all have below-average levels of productivity (Table 3). 
Table 3. Employment and productivity changes in Shanghai, 2003-09

\begin{tabular}{|c|c|c|c|c|c|c|c|c|c|}
\hline \multirow[t]{2}{*}{ Economic activities } & \multicolumn{2}{|c|}{$\begin{array}{l}\text { Total employment } \\
(2003)\end{array}$} & \multicolumn{2}{|c|}{$\begin{array}{l}\text { Total } \\
\text { employment } \\
(2009)\end{array}$} & \multicolumn{3}{|c|}{$\begin{array}{l}\text { Employment Change (2003- } \\
\text { 09) }\end{array}$} & $\begin{array}{l}\text { GDP/jobs } \\
(10,000 \\
\text { Yuan) } \\
(2009)\end{array}$ & $\begin{array}{l}\text { Real } \\
\text { productivit } \\
\text { y } \\
\text { change(\%) } \\
(2003-09)\end{array}$ \\
\hline & Number & $\begin{array}{l}\text { Share } \\
(\%)\end{array}$ & Number & $\begin{array}{l}\text { Share } \\
(\%)\end{array}$ & $\begin{array}{l}\text { Number } \\
\text { of jobs } \\
(10,000)\end{array}$ & $\begin{array}{l}\text { Weight } \\
\text { (\%) }\end{array}$ & $\begin{array}{l}\text { Rate of } \\
\text { change } \\
(\%)\end{array}$ & & \\
\hline All & 813.05 & 100 & 1064.42 & 100 & 251.37 & 0.0 & 30.9 & 14.14 & 61.99 \\
\hline Primary sector & 73.72 & 9.07 & 48.53 & 4.56 & -25.19 & -4.51 & -30.4 & 2.35 & 63.82 \\
\hline Secondary sector & 317.12 & 39.00 & 423.03 & 39.74 & 105.09 & 0.74 & 33.4 & 14.19 & 26.61 \\
\hline Industry & 281.69 & 34.64 & 333.69 & 31.34 & 52.00 & -3.3 & 18.5 & 16.21 & 40.36 \\
\hline Manufacturing & 276.02 & 33.95 & 327.86 & 30.80 & 51.84 & -3.15 & 18.8 & n.a & n.a \\
\hline Construction & 35.43 & 4.36 & 89.34 & 8.39 & 53.91 & 4.04 & 152.2 & 6.64 & -21.78 \\
\hline Tertiary sector & 422.21 & 51.93 & 592.86 & 55.70 & 170.65 & 3.77 & 10.4 & 15.07 & 85.12 \\
\hline
\end{tabular}




\begin{tabular}{|c|c|c|c|c|c|c|c|c|c|}
\hline Transportation, storage, post\&telecom & 45.90 & 5.65 & 54.28 & 5.10 & 8.38 & -0.55 & 18.3 & 11.70 & 54.25 \\
\hline Information, computing and software & 7.10 & 0.87 & 19.03 & 1.79 & 11.93 & 0.91 & 168.2 & 31.62 & -13.47 \\
\hline Retails and wholesale & 113.80 & 14.00 & 175.32 & 16.74 & 61.52 & 2.47 & 54.1 & 12.46 & 119.13 \\
\hline Accommodation and restaurants & 23.51 & 2.89 & 42.79 & 4.02 & 19.28 & 1.13 & 82.0 & 5.57 & -16.93 \\
\hline Finance & 17.32 & 2.13 & 22.11 & 2.08 & 4.79 & -0.05 & 27.6 & 81.60 & 99.35 \\
\hline Real estate & 28.87 & 3.55 & 36.55 & 3.43 & 7.69 & -0.12 & 26.6 & 33.86 & 85.61 \\
\hline Leasing and business services & 21.60 & 2.66 & 55.46 & 5.21 & 33.86 & 2.55 & 156.8 & 11.58 & 166.29 \\
\hline $\begin{array}{l}\text { Scientific research, technical service } \\
\text { and geological prospecting }\end{array}$ & 12.39 & 1.52 & 33.60 & 3.16 & 21.21 & 1.63 & 171.2 & 10.32 & 51.65 \\
\hline $\begin{array}{l}\text { water conservation, environmental } \\
\text { and public facility management }\end{array}$ & 7.72 & 0.95 & 11.36 & 1.07 & 3.64 & 0.12 & 47.2 & 3.97 & -46.73 \\
\hline Resident and other services & 73.43 & 9.03 & 63.34 & 5.95 & -10.09 & -3.08 & -13.7 & 2.48 & 158.85 \\
\hline Education & 27.54 & 3.35 & 29.20 & 2.74 & 1.66 & -0.64 & 6.0 & 12.95 & 94.90 \\
\hline Health, social security and welfare & 16.33 & 2.01 & 19.58 & 1.84 & 3.25 & -0.17 & 19.9 & 11.62 & 79.37 \\
\hline Culture, sports and entertainment & 8.14 & 1.00 & 11.99 & 1.13 & 3.85 & 0.12 & 47.2 & 7.30 & -27.78 \\
\hline Public administration and social & 18.56 & 2.28 & 18.25 & 1.71 & -0.31 & -0.57 & -1.7 & 17.98 & 199.96 \\
\hline
\end{tabular}




\begin{tabular}{|l|l|l|l|l|l|l|}
\hline organisations & & & & & & \\
\hline
\end{tabular}

Source: Shanghai Statistical Yearbook, 2006 and 2010. Own calculation. 
Third, judged by productivity and employment increases, only two sectors, i.e. retail and wholesale trade, and leasing and business services, stand out: over 2003-2009, their productivity rose by $119 \%$ and $166 \%$ respectively and their employment by 615,200 and 338,600 respectively. However, both sectors' productivities are below average, which indicates that they are unlikely to be serving high-end international customers. On the other hand, while the sector of information, computing and software registered the third highest productivity and added 119,000 jobs over 2003-2009, its productivity declined over this period. Moreover, its share in total employment is still very small (2\% in 2009). Finally, the category of transport, storage and postal services and telecommunication, important to the 'Four Centres' function, lost employment weight and experienced belowaverage productivity growth. In summary, it would seem that Shanghai has had rather limited success in developing specialised producer services.

\subsubsection{Economic Growth}

Shanghai's smaller economic size relative to Hong Kong was once considered as an important disadvantage (Shi \& Hamnett 2002). However, in the past two decades, Shanghai has made major strides in this respect. Starting with an economy only $21 \%$ of Hong Kong's size in 1990, Shanghai's GDP surpassed Hong Kong for the first time in 2009 (Leung 2011). Not only was this 26 years earlier than expected byShi \& Hamnett (2002), it was apparently 9 years earlier than expected by Hong Kong Trade Council(Leung 2011). Rapid population growth and the relative appreciation of the renminbi helped. 
The above examination shows that, although Shanghai has made some progress in global city formation and in enlarging its economy, it is still limited in developing specialised financial and business services, not to mention global control capability. IAs an emerging global city, it is still overshadowed by Hong Kong, and is behind Beijing in important ways. Structurally, Shanghai's transition from an industry-oriented economy to a service-oriented economy has only just begun. These are the consequences of the many constraints on the local and central state's capacity to intervene.

\section{Constraints on the state}

3.1. Inflexibility in the orientation of the state-market relationship

There are three particularly important issues here. First, the physical distance between Shanghai and the Chinese capital Beijing is a major disadvantage to Shanghai. As a socialist market economy, China's current economic system is characterised by strong state ownership of important assets, especially in the financial and industrial sectors. A majority of the Chinese financial institutions, including the four largest Chinese banks, and Chinese TNCs are owned by the central government and headquartered in Beijing. Indeed, since the relocation of the Bank of Telecommunications from Beijing to Shanghai in 1990, no other major Chinese bank has followed suit. On the other hand, of the 42 Chinese companies featured among the Fortune Global 500 companies in 2010, $30(71 \%)$ were headquartered in Beijing, three in Shanghai, two in Shenzhen, one in Hong Kong, with the rest (six) in five other cities inside China. ${ }^{2}$

${ }^{2}$.www.researchbank.co.uk (accessed 28 June 2011). 
Second, as a transitional economy, China is far behind Hong Kong in economic openness and freedom, something much valued by international financial investors and institutions. According to the Fraser Institute, which compiles the Economic Freedom of the World report, Hong Kong has maintained its top spot as the world's freest economy since the 1980s. Meanwhile, China occupies the 82nd place in the Economic Freedom Index in $2010 .^{3}$ Thus Shanghai continues to lag significantly behind Hong Kong in terms of market development (Subacci et al 2012).

The third issue is the continuing non-convertibility of the renminbi. Here the central government is concerned about balancing the gradual relaxation of exchange control, crucial to China's financial internationalization as well as Shanghai's global city status, and the minimisation of possible risks that this relaxation might bring the real economy, especially export-oriented manufacturing. China introduced current account convertibility in 1996, but retains capital account non-convertibility. To minimise risk, the centre has apparently decided to use Hong Kong as the launch pad for the gradual internationalisation of the renminbi. It has actively supported the development of Hong Kong as its preferred offshore centre for renminbi-denominated assets (Liu and Chiu 2009). It would seem that, as a catalytic state, the central government is using Hong Kong, which officially retains a capitalist system until 2047, to manage China's financial internationalisation. Thus Shanghai is unable to benefit from the historic opportunity of internationalising the renminbi, at least for the moment.

\subsection{Central-local politics}

\footnotetext{
${ }^{3}$ http://www.freetheworld.com/2010/reports/world/EFW2010-exec-sum.pdf. Accessed 28 June 2011. The Index takes into account of: 1. Size of Government: Expenditures, Taxes, and Enterprises; 2 Legal Structure and Security of Property Rights; 3 Access to Sound Money; 4 Freedom to Trade Internationally; 5 Regulation of Credit, Labor, and Business.
} 
Both theory (Jessop 1990; Friedmann 1986; Olds and Yeung 2004) and practice (e.g.Wang 2003) suggests that there are often divergent interests between the central and local governments in global city-making. Despite the unitary party-state, this is also the case in China (Beeson 2009). While the central government is primarily interested in strengthening its power both at home and abroad, local government is more concerned about maintaining strong revenue streams and promoting local economic growth. However, in a transitional economy like China's, policy concessions from the centre bestow important economic advantages on those that are either liberalised or allowed to liberalise before others. Recent studies of the relationship between network centrality and power in the World City Network literature shed useful light on this issue. Neal (2011) demonstrates that 'a city's powerfulness depends on the lack of centrality of the cities to which it is connected.' (p. 1). Thus a city like Hong Kong that has the central government's blessing can go a long way in its global city formation, as such blessing effectively enhances Hong Kong's power by maintaining the low centrality of other Chinese cities.

In its relationship with the centre, Shanghai has not fared very well in recent years. For instance, the share of the revenue that Shanghai can claim from stamp duty receipts has been gradually reduced from $50 \%$ to $20 \%$ (from 1997 ), then to $12 \%$ and eventually $3 \%$ (from October 2000 onwards) (Wang 2011, p. 43). While it initially benefited from substantive policy concessions from the central government through the establishment of the Pudong New Area in the early 1990s, its policy advantage has been weakened in recent years by the establishment of the Binhai New Area in Tianjin (in the north) in 2004 and the designation of the Liangjiang New Area in Chongqing (in the west) in 2010. A related fact is that, with the departure of Jiang Zemin (the former Chinese President and 
Shanghai ex-mayor) from Chinese politics in 2003, Shanghai has lost a strong supporter in the central government. On the other hand, Shanghai has shown weaknesses in its governance and its relationship with the wider region. Shanghai Municipality's reputation was tarnished by the discovery of misuse of its pension fund (for property speculation) in 2006 and the consequent removal (in 2006) and eventual imprisonment of its former powerful boss (Party Secretary) Chen Liangyu in 2008 for 18 years. On the other hand, Shanghai's performance as the 'dragon head' of the Yangtze River Delta and Yangtze Basin lacks the depth and breadth of the economic links between Hong Kong and its hinterland, the Pearl River Delta (Sung 2011). The most recent central government pronouncement (2009) on Shanghai contains few real concessions, except for furthering Shanghai's shipping centre function.

\subsection{Inter-city competition}

Given administrative decentralisation, Chinese cities and provinces are constantly in competition with each other over winning policy concessions from the central government and winning businesses in various markets. The commodity 'wars' erupted in the 1980s have been followed by furious competition for high-value financial and business services. Shanghai is challenged not only by its traditional competitors such as Hong Kong, Beijing and Shenzhen, but also by Tianjin and Chongqing. Perhaps as recognition of this situation, Shanghai's $12^{\text {th }}$ Five-year Plan proposes that by 2015, the city's share in the direct capital raised in the domestic capital market should reach $30 \%$ (up from $25 \%$ in 2010), much lower than one might expect.

Competition with Hong Kong is surprisingly strong. This is partly due to the deft way in which the Hong Kong Special Administrative Region has handled its relationship with the 
central government in Beijing. Successive Governors and their administrations have tirelessly sought to gain policy concessions from Beijing and increass integration with the mainland in order to benefit from the latter's prosperity. For instance, shortly after the completion of the $11^{\text {th }}$ national Five-year Plan, Hong Kong started to explore how 'Hong Kong should be involved in the preparation of the $12^{\text {th }}$ five-year plan' despite its autonomous status (Liu and Chiu 2009). This has paid off. While the $12^{\text {th }}$ Plan contains only one mention of Shanghai's function as 'four centres', it devotes almost a whole paragraph to Hong Kong and states

To continuously support Hong Kong to develop finance, shipping, logistics, tourism, professional services, IT and other high value-added services; support the development of Hong Kong as an offshore renminbi transaction centre and international wealth management centre; support Hong Kong's development in high-value warehouse management and regional wholesale centre; consolidate and raise Hong Kong's status as an international financial, trade and shipping centre; strengthen its global influence as a financial centre (NDRC 2011, p. 123, the author's translation).

Following this, the central government announced a set of 36 supportive measures for Hong Kong in August 2011 (Lianhe Zaobao, 18 August 2011).

\subsection{Other constraints}

Shanghai's attempt to develop global control functions has so far suffered from a number of other constraints. For instance, like other Chinese coastal cities, Shanghai in the early 2000s aggressively engaged in place-making activities through large-scale real 
estate development (Wu 2009). However, concerned with spiralling real estate prices and the possible threat to social stability, from the mid-2000s the central government has introduced a series of increasingly tough policy measures to dampen this sector's expansion (Wang 2011). As a consequence, the real estate sector has stagnated in Shanghai in recent years (Table 3).

On the other hand, as shown earlier, Shanghai has found it difficult to reduce more quickly its large manufacturing sector to replace it with high-value service jobs. It has failed to add jobs where labour productivity is high and only succeeded where productivity is relatively low. It has also been weak in creating jobs in education, health, personal and social services (Table 3). Thus Shanghai has been slow in developing 'knowledge complexes'.

There is also strong evidence that policy actions by the Municipality have at times been constrained by changing national policy priorities. Analysis of the Municipality's annual work plans since 2004 shows that the Municipality has grappled with changing central priorities echoing the centre's: kejiaoxingshi (development through science and education) (2004-06); development of resource-efficient economy and eco-friendly society (2006-08); development of the 'Four Centres' and industrial upgrading (especially towards modern services) (2006-2010), while comprehensive reform in Pudong and the preparation and delivery of the World Expo were on the agenda throughout. ${ }^{4}$

\footnotetext{
4 Shanghai Municipality has published online its annual work program since 2004. http://www.shanghai.gov.cn/shanghai/node2314/node2319/node22396/index.html (accessed 8 March 2011). Each annual programme covers 20 or so task areas.
} 
By contrast, Hong Kong has been largely left alone to focus on its strategy of becoming China's premium service provider, as well as investment and tourist destination. On the other hand, by exploiting the opportunities created by mainland China's recent economic expansion and through ever closer integration with the Pearl River Delta (and even the rest of China), and by positioning itself within the national planning system, Hong Kong has been able to make itself more global as well as more Chinese. Liu and Chiu (2009) observe: "Instead being disembedded from the larger national and regional contexts, Hong Kong is becoming a Chinese global city." (p. 115).

\section{Conclusions}

Despite persistent efforts by the local authority and rising national economic power, Shanghai's progress in global city formation is relatively slow. This is due to the numerous external and internal constraints that the city government is under, as well as underlying economic barriers. While some of the constraints (e.g. dominant state ownership; the West's hostility) are specific to China, numerous others, including:

(i) the relatively under-developed condition of the market and institutions;

(ii) competition from other domestic cities;

(iii) national-local politics, as well as

(iv) the inherent difficulty in developing knowledge complexes and global corporate control capability in a transitional emerging economy context; may apply to other emerging global cities.

Nevertheless, the rise of Hong Kong, Beijing and Shanghai shows that there is good prospect for emerging global cities. Moreover, the central state can play an important role by stimulating economic growth and implementing liberalisation. In particular, like 
Tokyo and Seoul, Beijing's ascendance shows that fostering domestic TNCs is at least as important as attracting other TNCs.

As for the global/world city scholarship, this study demonstrates that greater attention needs to be paid to studying the dynamics of how fast economic growth, domestic socioeconomic characteristics, activities of home-grown TNCs and emerging economies' internationalisation strategies can significantly influence global city formation.

Acknowledgement: I wish to thank the three anonymous reviewers for their constructive comments on earlier versions of this article, and Prof Nigel Harris for his generous advice on the final revision. 


\section{References}

Beeson, M. 2012, "Developmental States in East Asia: A comparison of the Japanese and Chinese Experiences", Asian Perspective, 33 (2), pp. 5-39.

Braudel, F. 1984, The Perspective of the World, London: Collins.

Bureau of Shanghai Urban Planning and Building Administration (BSUPPA) 1986, The Comprehensive Plan of Shanghai Shanghai.

Castells, M. 1996, The rise of the network society. Blackwell, Oxford.

Chang, H.-J. 2003, Globalization, Economic Development and the Role of the State Zed Books, London.

Chen, X. (eds.) 2009, Shanghai: State Power and Local Transformations in a Global Megacity, University of Minnesota Press, Minneapolis.

Friedmann, J. 1986, "The world city hypothesis", Development and Change, 17(no. 1), pp. 69-84. DOI: 10.1111/j.1467-7660.1986.tb00231.x

Friedmann, J. 1995, "Where we stand: a decade of world city research," in World cities in a world-system, P. L. Knox \& P. J. Taylor, eds., Cambridge University Press, Cambridge, pp. 21-47.

Friedmann, J. 2001, "World Cities Revisited: A Comment", Urban Studies, 38, pp. 25352536. doi: 10.1080/00420980120094641 
Friedmann, J. \& Wolff, G. 1982, "World city formation. An agenda for research and action", International Journal of Urban and Regional Research, 6 (3), pp. 309-344. DOI: $10.1111 / j .1468-2427.1982 . t b 00384 . x$

Hall, P. 1966, The World Cities McGraw-Hill, New York.

Hill, R. C. \& Kim, J. W. 2000, "Global cities and developmental states: New York, Tokyo and Seoul", Urban Studies, 37, pp. 2167-2195. DOI: 10.1080/00420980020002760

IMF 2000, Transition Economies: An IMF Perspective on Progress and Prospects IMF, Washington.

Jao, Y. C. 2003, Shanghai and Hong Kong as international financial centres: Historical perspective and contemporary analysis. Working paper 1071 from University of Hong Kong, The Hong Kong Institute of Economics and Business Strategy, Hong Kong.

Jones, G. 1992, "International Financial Centres in Asia, the Middle East and Australia: A Historical Perspective," in Finance and Financiers in European History 1880-1960, Y. Cassis, ed., Cambridge University Press, Cambridge, pp. 405-428.

Kindleberger, C. P. 2000, "The Formation of Financial Centers," Comparative Political Economy, The MIT Press, London, England, pp. 241-317.

King, A. D. 1990, Global Cities: Post-Imperialism and the Internationalisation of London Routledge, London and New York.

Knox, P. L. 1995, "World cities in a world-system," in World cities in a World System, P. L. Knox \& P. J. Taylor, eds., Cambridge University Press, Cambridge, pp. 3-20. 
Leading Group of "Shanghai towards the 21st Century" Research Project 1994, Shanghai Towards the 21st Century: A Study of Economic and Social Development Strategies for Shanghai (1996-2010) Shanghai Renmin Press, Shanghai.

Leung, S. "Hong Kong's Economy Overtaken by Shanghai in 2009 (Update2)", Bloomberg 5 March 2010. Lui, T.-L. \& Chiu, S. W. K. 2009, "Becoming a Chinese Global City: Hong Kong (and Shanghai) beyond the Global-Local Duality," in Shanghai by X. Chen, ed., pp. 93-121.

Mainelli, M. \& Yeandle, M. 2007, The Global Financial Centres Index1 The City of London, London.

McCauley, R. N. \& Chan, E. 2007, "Hong Kong and Shanghai: Yesterday, today and tomorrow," in Financial Sector Development in the Pacific Rim, East Asia Seminar on Economics Volume 18, T. Ito \& A. Rose, eds., University of Chicago Press, Chicago..

Neal, Z. P. 2010, Differentiating Centrality and Power in the World City Network GaWC Research Bulletin 365.

National Development and Reform Commission (NDRC) 2011, National Economic and Social Development Twelfth Five-year Plan (full text), NDRC, Beijing, in Chinese. http://www.ndrc.gov.cn/fzgh/ghwb/gijh/P020110919592208575015.pdf (accessed 31 May 2013)

OECD 2008, Globalisation and Emerging Economies: Brazil, Russia, India, Indonesia, China and South Africa, OECD, Paris.

Olds, K. \& Yeung, H. 2004, "Pathways to global city formation: a view from the developmental city-state of Singapore", Review of International Political Economy, 11(3), pp. 489-521. DOI: $10.1080 / 0969229042000252873$ 
Ryoichi, H. 2011, "Tokyo's changing role as a financial center since the seventeen century," in Gateways to Globalization: Asia's International Trading and Finance Centres, F. Gipouloux, ed., Edward Elgar, Cheltenham, UK and Northampton, MA, USA, pp. 2950.

Sassen, S. 1991, The Global City: New York, London, Tokyo Princeton University Press, Princeton.

Sassen, S. 2001, The Global City: New York, London and Tokyo, 2nd edn, Princeton University Press, Princeton, NJ.

Shanghai Municipal Government (SMG) 2011, Shanghai Economic and Social Development Twelfth Five-Year Plan, SMG, Shanghai. In Chinese. . Available from http://www.sh.gov.cn.

Shi, Y. L. \& Hamnett, C. 2002, "The potential and prospect for global cities in China: in the context of the world system", Geoforum, 33, pp. 121-135. PII: s0016-7185(0)0026-4

Subacchi, P., Huang, H., Molajoni, A., \& Varghese, R. 2012, Shifting Capital: The Rise of Financial Centres in Greater China, A Chatham House Report, The Chatham House, London.

Sung, Y.-W. 2011, "Hong Kong and Shanghai: rivalry or complementarity among Asia's international service hubs?" in Gateways to Globalization: Asia's International Trading and Finance Centres, F. Gipouloux, ed., Edward Elgar, Cheltenham, UK; Northampton, MA, USA, pp. 101-116. 
Talyor, P. J. 2000, "World Cities and territorial states under conditions of contemporary globalization", Political Geography, 19, pp. 5-32. PII: s0962-6298(99)00060-8

Taylor, P. J. 2004, World City Network: A Global Urban Analysis Routledge, London and New York.

Taylor, P. J., Ni, P., Derudder, B., Hoyler, M., Juang, J. and Witlow 2011, Global Urban Analysis: A Survey of Cities in Globalization Earthscan, London and Washington, DC.

Wallerstein, I. 2004, World Systems Analysis: An Introduction. Duke University Press, Durham; London.

Wang, C.-H. 2003, "Taipei as a Global City: A Theoretical and Empirical Examination", Urban Studies, 40 (2), pp. 309-334. doi: 10.1080/00420980220080291

Wang, L. 2011, Foreign Direct Investment and Urban Growth in China Ashgate, Farham, England.

Weiss, L. 1997, "Globalization and the Myth of the Powerless State", New Left Review no. $1 / 225$, pp. 3-27.

Weiss, L. 1998, The Myth of the Powerless State: Governing the Economy in a Global Era Polity Press, Cambridge.

Wooldridge, A. “Special Report: State Capitalism”, The Economist, January $21^{\text {st }} 2012$.

Wu, F. 2009, "Globalization, The Changing State, and Local Governance in Shanghai," in Shanghai by X. Chen, ed., pp. 125-144.

Yeandle, M. 2012, TheGlobal FinancialCentres Index 11, Long Finance/Financial Centre Futures, London. 
Zhang, L.-Y. 2003, "Economic Development in Shanghai and the Role of the State", Urban Studies, 40 (8), pp. 1549-1572. DOI: 10.1080/0042098032000094423

Zhang, L.-Y. 2006, "Market Socialism Revisited - The case of Chinese state-owned enterprises", Issues \& Studies, 42 (3), pp. 1-46.

Z/Yen Ltd 2005, The Competitive Position of London as a Global Financial Centre Z/Yen Limited, London. 